\title{
Article
}

\section{The Political Logic of Victim Impact Statements}

\author{
Rosebury, Brian
}

Available at http://clok.uclan.ac.uk/3398/

Rosebury, Brian ORCID: 0000-0002-6154-2685 (2011) The Political Logic of Victim Impact Statements. Criminal Justice Ethics, 30 (1). pp. 39-67. ISSN 0731-129X

It is advisable to refer to the publisher's version if you intend to cite from the work. http://dx.doi.org/10.1080/0731129X.2011.559061

For more information about UCLan's research in this area go to http://www.uclan.ac.uk/researchgroups/ and search for <name of research Group>.

For information about Research generally at UCLan please go to http://www.uclan.ac.uk/research/

All outputs in CLoK are protected by Intellectual Property Rights law, including Copyright law. Copyright, IPR and Moral Rights for the works on this site are retained by the individual authors and/or other copyright owners. Terms and conditions for use of this material are defined in the policies page.

\section{CLoK}

Central Lancashire online Knowledge www.clok.uclan.ac.uk

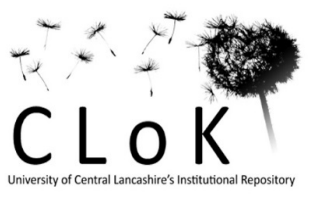


Author Posting. (c) John Jay College of Criminal Justice, City University of New York, 2011.

This is the author's version of the work. It is posted here by permission of John Jay College of Criminal Justice

CUNY for personal use, not for redistribution.

The definitive version was published in Criminal Justice Ethics, Volume 30 Issue 1, April 2011.

doi:10.1080/0731129X.2011.559061 (http://dx.doi.org/10.1080/0731129X.2011.559061)

\section{The Political Logic of Victim Impact Statements}

\section{BRIAN ROSEBURY}

The guilty get a good run in our judicial system while victims can be a dirty word. It's the world turned upside down. . . .

Prominent defence lawyer Rob Stary, a member of the Law Institute's Criminal Law Section, believes victim impact statements provide the opportunity to find out how the victim feels. . . "They are cathartic in their nature, they're helpful for the victim to articulate their positionand that's important - and allow the judge when they're determining penalty to understand the immediate long-term consequences," he explained. "Most judges, despite a view that they are removed from the community, in fact are highly sensitive to the impact upon victims. That's reflected in sentencing comments all over the place."

Stary and I agree to disagree on this point. ${ }^{1}$

\section{Introduction: a political context}

In this paper I discuss three aspects of the continuing debate over the use of Victim Impact Statements (VIS) in criminal proceedings. I aim to show, in each case, the dependence of key arguments in favor of VIS on presuppositions that can be characterized as political, in the sense that they enter the debate not so much through argumentation internal to the ethics of 
criminal justice, as through the influence of a wider popular and media consensus about the entitlements of a citizen and the failings of the criminal justice system. I will focus primarily upon those arguments for VIS that frame them within a discourse of "justice" rather than "welfare," but I will acknowledge and distinguish the latter when necessary. I hope that one contribution of the paper will be to assist clarification of the distinction, and to promote reconsideration of the weight each type of justification can carry.

An intimate relationship between the discourses of criminal justice and of the wider political realm is inevitable and indeed desirable. Both are informed by the attempts of people of goodwill to think rationally about deep and contested moral values, while keeping in clear view the general and specific facts of human life. We should set aside, plausible though it may sometimes seem, the notion of a wholly irrational popular sentiment beating down upon, and potentially corroding, the sober deliberations of the legislators and the courts. Instead I want to show, by evaluating certain arguments for VIS, that they are open to objections that can be successfully refuted if, and only if, influential, and rather specific, political presuppositions are brought to their aid. I do not aim to disprove or discredit these presuppositions, only to demonstrate their role in the case for VIS, though I believe we may think differently about the moral and political context of VIS if the analysis is accepted.

What are these presuppositions, and how have they arisen? In contemporary western culture, most people believe that our social and political apparatus, including law, has value to the extent that it serves or facilitates individual well-being. The individual life is the locus of value; social goods are ultimately reducible to an aggregate of individual goods. This is not a universal or necessary view, and various conservative, religious, and communitarian traditions offer alternatives, mainly by affirming the existence of intrinsic or irreducibly social goods, ${ }^{2}$ or by assailing the concept of individual autonomy. But it is the dominant belief, natural to a liberal democracy. And within it, often only loosely corresponding to 
political party allegiances, there are two distinct views of the role of the state and other public agencies in contributing to individual goods. Both assume that individual human beings are, by and large, rational decision makers: but they take different views of the kind of society to that our rational decision making should lead us, and that in turn can best support our future choices. The crucial difference, simply stated, is that one view envisages (and prefers) a society of individually acting individuals, the other a society of individually and collectively acting individuals. $^{3}$

On the first view, broadly identifiable with market liberalism, the members of the society are viewed as an aggregate of rationally self-interested and inherently competitive individuals, each seeking his or her due, and pursuing his or her preferences. Economic activity is regulated by law, in order that the competition among individuals is fair and peaceful, but admits as little intervention by the state or other collective agencies as is consistent with the safe and effective operation of the market. Thanks to the invisible hand of the market, all—more or less—-benefit from the competitiveness of each. The moral imperative governing our activity in the economic sphere is to compete lawfully as an individual, honoring contracts and expecting fair reward. To combine with others, except in the context of contractual relationships among persons, such as those between buyer and seller or employer and employee, is morally questionable on two counts: we surrender dignity and autonomy, and we fall under suspicion of seeking to distort the market, through cartels or the intrusion of political power.

Market liberalism has its origins in classical economics, but took on its distinctive present-day political character in the later twentieth century, in reaction against the apparent spread and prestige of centrally-directed economic systems, most menacingly exemplified by the Soviet Union. Political economists such as Hayek and Friedman criticized state intervention in the market, not merely for compromising its efficiency as a mechanism for 
expressing individual choice, but as necessitating definite repressions of liberty. A system of state intervention, in the name of welfare, redistribution or "positive liberty," would empower a governing elite, liable to "declare almost any interest a general interest and ... make large numbers serve purposes in which they are not in the least interested" [italics added]. ${ }^{4}$ To this analysis, the libertarianism of Nozick added the claim that distributions resulting from lawful free market activity were ipso facto just, and that government intervention in pursuit of a planned distribution could not but violate individual rights. ${ }^{5}$ At a popular level, these beliefs have helped to form a consensus, or at least a widespread sentiment, that the state and its taxfunded agencies (“big government”) stand in natural opposition to our individual interests and wishes. In this discourse, the idea that the agencies of the public realm might be serving to advance our collective interests, not least by limiting and policing the economic power of the very rich, is ignored or debunked. Indeed, market-dominant private media interests are able to cast themselves as opponents of an "establishment" that comprises "institutions hungry for power at the expense of ordinary citizens." 6

The alternative, social liberalism, rejects market liberalism's identification of collective action with institutional coercion. Social liberalism emphasizes the capacity of rational individuals to choose to act collectively, whether through voluntary organizations such as labor unions, or, as willing taxpayers and compliant citizens, by suspending or subordinating the competitive pursuit of individual goods in deference to public institutions supposed to facilitate the good of all. Since a degree of self-abnegation, at least in the short term, seems to be required if individual choices are to be pooled in this way to sustain collective action, social liberalism needs to explain why such a sacrifice is justified, and indeed psychologically possible, if all good is individual good. It may appeal, for example, to a Rawlsian moral psychology, in which just institutions enjoy popular consent precisely in virtue of their manifest justice ("justice" understood, at least in part, as the assurance of due 
care for the welfare of all individuals including the least fortunate). ${ }^{7}$ Or it may appeal to the recognition - most commonly expressed today in the discussion of environmental policythat uncoordinated choices can be self-defeating, that an aggregate of purely individuallymotivated choices can create outcomes that nobody wants. ${ }^{8}$ For social liberals, markets are not expected to convert individual competition into outcomes more or less good for all. Rather, the moral imperative for each of us is to aim for the best outcomes, judging whether these are most likely to be secured by our own individual action, or by subsuming our action into that of a group or public institution.

There can be little doubt that in the period between the election of Ronald Reagan as US President in 1980 and the economic collapse of 2008, the market-liberal view gained strength, winning adherents widely among the intelligentsia, in active political life, and in the media. I will argue that the rise of VIS is intimately related to this development. It is connected to the idea of members of society as competitively seeking their personal good, as they themselves define it, against the background of a diminished expectation that they should repose their confidence in public institutions.

Why would it matter if this claim proved to be true? On one view, it would matter very little, except to historians of ideas. It would, at most, provide an example of an idea in one field becoming a stronger candidate for acceptance because of the presuppositions it shares with other, increasingly widely-accepted, beliefs. On another view, it would matter considerably. It might be a bad thing for the criminal law, for example (that is, for the respect in which it is held), that it should come to be seen primarily as an arena in which individuals struggle to get their due.

That there is some affinity between the case for VIS and the values of market liberalism may seem obvious, since the assertion of individual entitlements and preferences plays a key role in both. ${ }^{9}$ The main contribution of this paper will be to analyze more fully 
the structures of (sometimes implicit) argument that unite the presuppositions needed to defend VIS with those of market liberalism, in particular its anti-collectivism and anti-statism. Whatever substantive philosophical interest the paper may possess will lie in these analyses (sections IV-VI); the much shorter sections that precede and follow these three are intended to provide some necessary context, and to suggest, more polemically, a relation to continuing wider political debate and conflict.

Before leaving the wider political context for the present, it is worth heading off one misunderstanding right away. To maintain that there are logical connections between VIS and market liberalism is not to deny that the victim's "voice" can be enlisted for policy initiatives that are not "liberal" in any sense. This is the theme of Markus Dirk Dubber's (2004) study of the victims' rights movement in the USA. Dubber argues that the political success of the movement in the 1980s was compromised by its assimilation to "the war on crime" ... a "mass incapacitation campaign" aimed at perceived antisocial elements, and carried out through an expansion of "the state's system of criminal administration." Dubber traces this development to a "state-centered, preconstitutional" model of criminal justice, inherited from eighteenth-century England. ${ }^{10}$ But, even according to his own account, there was no logical connection between this authoritarian project and the vindication of victims' rights: the connection, as he puts it, was merely one of "fact," not "principle," with public indignation over the suffering of victims providing political cover for aggressive, class-driven measures of social control, unconnected to any direct redress for victims. ${ }^{11}$ In contrast, when Dubber begins to defend what he believes to be "the legitimate core of victims' rights" [italics added], his own anti-statist individualism is at once apparent.

For too long, American criminal law has been run by the state in the name of ill-defined "public interests." . . Crime is not a public health issue but a 
traumatic experience shared by two persons, the offender and the victim. ${ }^{12}$

Dubber is unusual among skeptics about VIS in interpreting its rise as much in the light of the first assertion as of the second, and in viewing it with suspicion for that reason. As we shall see — and as might be expected — among sympathetic accounts of VIS, it is the second remark that is more characteristic.

\section{Distinguishing the functions of the victim statement}

An important preliminary step is to "unpack" the ambiguous concept of VIS by identifying certain distinct aspects of victim input that may inhere in the same actual victim utterance (1) Victim Impact Evidence (VIE)

In its aspect as Victim Impact Evidence, the function of the victim utterance is to inform the court of the harm actually caused by the offense to its immediate victim, or to other persons closely affected such as family members or rescue workers. Any other purposes that may be simultaneously served by the victim utterance are not relevant to "strict VIE" as I will call it. The victim, so far as strict VIE is concerned, has no special human status as a participant in the court proceedings. Though it may be necessary for her to narrate her experiences, or express psychological states such as emotions, her impact evidence is on the same footing as non-expressive evidence, such as clinical evidence of injuries caused, or quantitative assessments of damage to property. The victim's role in VIE is similar to that of a witness, though her statements qualify as VIE only to the extent that they are directed to the harm she has suffered as a result of the crime.

(2) Victim Opinion Statements (VOS)

In a very few jurisdictions, victims or their survivors have been permitted to express opinions on the crime and on the proper penalty for the convicted offender. Such opinions, strictly understood, are not evidence, but are a judgment, passed from a distinctive perspective, on 
the implications of the evidence. In contrast to VIE, the especially relevant status of the victim or her survivors is precisely what justifies the admission of VOS. Indirectly, of course, VOS may reveal evidence of the victim impact suffered, and in practice (strict) VIE and (strict) VOS may be blended in the same utterance, but the courts must be presumed to be able to distinguish opinion from impact evidence and to treat each element appropriately.

\section{(3) Victim Statements (VS)}

This expression covers all utterances by victims in their capacity as victims that are admitted at any stage of the criminal justice process, whether before, during or after court proceedings. VIE and VOS are therefore specialized categories of VS. VS may include evidence of harm suffered, opinions on the proper penalty, expressions of compassion or forgiveness towards the offender, expressions of hatred and indignation, comments on proposals to grant bail or parole, attempts at reconciliatory or restorative dialogue and negotiation, complaints about the criminal justice processes themselves, and so forth.

\section{Justice and welfare justifications of VIS}

The justifications of victim input advanced by its advocates are also varied, but they can broadly be divided into two types, those directed to justice and those directed to welfare, or utility. On the one hand, VIE is claimed to be of value to the courts since it makes clearer the nature and extent of the harm done by the offense, and can therefore "enhance justice ... particularly in terms of sentence proportionality." ${ }^{, 13}$ On the other hand, Victim Statements generally, especially when presented in the context of some wider system such as a victim support regime or a restorative justice program, are claimed to bring benefit to various parties: to the victim or victim's survivors, to the offender, whose understanding of his crime and its effects may enhance his rehabilitation, and to society as a whole through the reduced alienation and increased co-cooperativeness of victims, and the introduction of a healing element into the management of criminal justice. ${ }^{14}$ Edna Erez notes a range of therapeutic or 
empowering effects recorded by victims. These include, inter alia: experiencing a "cathartic effect" after providing impact information; discharging their "civil duty"; redressing the "unequal balance" between themselves and the offender introduced by the crime; asserting "ownership of the conflict," which they may have "felt was misappropriated from them in the name of the state"; being able "to remind judges of the fact that behind the crime is a real person who is a victim"; and, in the case of the survivors of murder victims, fulfilling a compelling need to "represent the interests of their beloved one in the case."

Erez mentions the rare permissions of Victim Opinion Statements only in a footnote and without comment. One might suppose from this that victim opinion is rarely communicated, and it is true that even in those jurisdictions that have allowed VOS, such as Arizona, its use has been challenged on appeal, and that in most jurisdictions victim statements may not include proposals as to penalty. However, this picture is somewhat misleading because of the ease with which the logical distinction between (strict) VIE and (strict) VOS breaks down in rhetorical practice. The public impression in this respectnamely, that in some high-profile cases victim opinion has been vividly communicated in court - is not unfounded. For example, at the trials of the Oklahoma bomber Timothy McVeigh and the 9/11 conspirator Zacarias Moussaoui, the presentation of hours of heartrending impact evidence by victims' survivors, in the context of prosecution calls for the death penalty, made it superfluous for the participants to breach the rules by formally expressing their opinions on the appropriate sentence. They had, in effect, expressed an opinion by their decision to appear. The same is no less true of those whose statements, as in the case of McVeigh's accomplice Terry Nichols, were called by the defense, and served to suggest that victim impact need not imply a capital sentence. ${ }^{16}$

Notwithstanding these qualms, the initial concern of many opponents of VIS - that they would sway courts towards vengeful sentencing — does not seem to have been borne out. 
Erez and others have produced evidence to suggest that their use has not led to a pattern of greater severity in sentencing. ${ }^{17}$

I turn now to the three questions.

\section{The rejection of the wholly public conception}

The first question concerns a fundamental aspect of our conception of criminal justice. As both supporters and critics of VIS have noted, their introduction challenges what might be called the wholly public conception, the doctrine that crimes are to be understood as offenses against the entire community, to be investigated and chastised by the public authorities, and not by, or even on behalf of, individual crime victims. Though classically stated by philosophers as different as Hobbes and Hegel, ${ }^{18}$ the wholly public conception became firmly entrenched only recently, partly thanks to the administrative reforms that made practicable prosecution by the state as a uniform system, and partly as a by-product of the gradual ethical and practical repudiation of the reliance on private prosecutions associated with such criminal justice regimes as the so-called "Bloody Code" in England. ${ }^{19}$

So firmly established in the educated consciousness has the wholly public conception been, until quite recently, that one assumes some canonical arguments in its favor must be ready to hand. Yet it tends in modern texts to be taken for granted rather than defendedalmost as if to defend it explicitly would be to concede the unnerving possibility of its abandonment. In the UK, for example, the Report of the JUSTICE committee on the role of the victim in criminal justice (1998) states, but does not argue for, the view that "the prosecutor is prosecuting on behalf of the state, not the victim." ${ }^{20}$ It adds that "victims can find it difficult to understand that the prosecutor's role is not to present their case, but to prosecute on behalf of the Crown," implying, without explaining why, that they should be brought to understand this. ${ }^{21}$ In 2004, the Irish Minister of Justice felt obliged to reminder a 
questioner in the Dáil that "Under the Constitution prosecutions are brought in the name of the people as a public act against the accused. In this country, as in many other countries, we have an adversarial system of trial.... The two sides, so to speak, are the people-acting through the public prosecution under the Director of Public Prosecutions - on the one hand and the accused on the other. It is not a three-cornered contest in which the victim, the alleged perpetrator and the people are at opposite ends of a triangle." Again, no justification was offered, beyond the assertion that the existing system was "fair.,"22

I will therefore review what seem to me to be the strongest available arguments in favor of the wholly public conception: these, I assume, are the arguments on which its defenders, at least tacitly, rely.

\section{(1) The definitional argument}

Law is, by definition, a social and institutional phenomenon. A crime, by definition, is a breach of the law, not merely an intentional or reckless harm to an individual person or persons. (To call it a "wrong" against a person would already be to invoke either the impersonal discourse of natural law, or the institutional discourse of positive law.) The prosecution of a crime is therefore appropriately a social and not an individual responsibility. Measures to repair or compensate the harms incidentally suffered by an individual victim of crime may be morally required of the community, but these are a matter for welfare agencies, not for the criminal justice process itself.

Like all definitional arguments, this one is open to the objection that the definition (of crime) is not self-justifying, and a sufficiently radical rethink of our terms could lead to its abandonment. It could be revised precisely to stipulate that a crime is a special category of harm to a person, who may therefore reasonably seek reparation (but need not choose to do so, just as one does not always put in an insurance claim): the institutions of criminal justice could be reconceived as services to ensure reparation to these individuals when they seek it. 
Criminal justice on this view would become the mission of a particular public service, and its radical distinction from welfare would disappear.

\section{(2) The communitarian argument}

Individual personhood is at least partly constituted by relations to other persons and to groups and communities: each person is "a part of the main," in Donne's words. Conversely, every community is at least partly constituted by its members' persons. Every crime therefore harms, or wrongs, not only an individual, but the community that is interdependent with that individual, even if there is no specific collateral harm to other individuals. The decision to seek redress and the responsibility for making it effective must therefore, at the very least, be shared between the wronged individual and her community.

Moreover, the expectation of the support of the community when one has been injured is an important motive for social co-operation. And the community is in any case more powerful than the individual. Therefore the responsibility to prosecute and punish crime, and ensure redress for the victim, should lie primarily with the community. Because the community is itself harmed by a crime, it may sometimes rightly decide to prosecute even when the wronged individual would prefer that it did not.

It is obvious that in its theory of the relation of individual personhood to other persons and to communities, the communitarian argument stands in opposition to liberal individualism (or at the other end of a spectrum of conceptions of the relation of the individual to society), and it is needless as well as impossible to pursue this deeper theoretical debate here.

However, it is worth noting one vulnerable point in the communitarian argument. If we defend the wholly public conception of criminal justice on the grounds that a harm to an individual is ipso facto a harm to the community on which the community must act, we need to say which kinds of intentional or reckless harm caused by one person to another should be 
criminalized. The answer to this question cannot be "all of them" (since this would lead to the criminalization of millions of minor interpersonal abrasions). We need a justification of the designation of certain harms, but not others, as criminal wrongs. If in seeking this we appeal to communal judgment, we risk making redress for an individual dependent on some contingent sociological fact. For example, it may be argued that a self-conscious group (such as women, or a religious or ethnic minority) will perceive a harm to one of their number as "their" wrong as well as "her" wrong. Even against the wishes of the harmed individual, the community might then properly insist on bringing a prosecution "on her behalf"; and this adoption of an individual's harm by a particular social group as its concern might serve, by way of analogy, to explain and justify the entire community's adoption of certain individual harms as its concern. But the scope of such adoption by the community of individuals' harms would always be a sociologically contingent matter (and indeed if it were not, it could not function to select some harms and not others). The argument is then open to the criticism that it leaves some individual rights at risk, since it is the essence of a political right, as generally understood, that it is owned irrespective of the sentiments of the wider community. The opponent of the wholly public conception could argue here, therefore, that the communitarian argument robs individual victims of sovereignty over "their" cases without providing an assured protective intervention in support of their rights. ${ }^{23}$

\section{(3) The participative equality argument}

All citizens have an equal obligation to obey the law, and to co-operate with its processes by, for example, furnishing information to the courts when asked to do so. Except in the case of those holding offices within the criminal justice system, who act in those capacities and not as private persons, no person must have a specially enhanced power in influencing the operation of justice. This prohibition applies no less to victims and offenders than to other 
citizens. Both are simply expected to serve the criminal justice process by furnishing truthful evidence.

Victims and offenders do indeed have distinctive rights, but they must not be active rights of influence over the judicial process itself. Rather they are protective rights, derived firstly from the requirements of justice itself (as when the accused person is protected from the disclosure of information that might prejudice a jury), and secondly from the objective of minimizing the distress caused by the criminal justice processes (as when a vulnerable witness is protected from exposure in open court or from aggressive cross-examination). A victim is, of course, deserving of additional care from the public authorities, commensurate with the harm she has suffered, but this is, again, a matter for welfare, not for criminal justice.

This argument cuts deeper. To counter it, to justify the abandonment of participative equality in favor of giving a victim active rights of influence over the operation of justice in "his or her" case, one would have to claim something like this: that the field of operation of criminal justice is an aggregate of individual arenas of interest governed by a unified system of law, rather than a single wholly public arena in which all have an equal interest. Within his or her individual arena of interest, the victim would then have special rights of influence and decision. The metaphor that suggests itself for this view of the victim's special interest is the assertion of ownership over a certain territory, comparable to the enclosure of common land, which creates privately owned spaces that are nevertheless subject to universal laws of property. Indeed, the phrase 'his or her case' already implies a private property metaphor.

\section{(4) The impartiality argument}

It is essential to criminal justice that its agents be free from any personal interest. The refusal of active rights of influence to a victim is captured in the dictum that a person must not be "a judge in his own case." As Hegel puts it, the magistrates must be supposed to be guided not by any "subjective will," but by "the universal will of the law." ${ }^{, 24}$ This applies no less to the 
prosecutor than to the judge. Any admission of the victim, tacitly or explicitly, as coprosecutor, as a person with a special interest, is at best redundant to the work of the magistrates, and at worst may undermine the consistent application of the law. Indeed, VIS may threaten to become a vehicle for private revenge, throwing into reverse the social evolution that created the (ideal) objectivity of legal trial and punishment out of the "war of each against each," endemic wherever private retaliation is accepted.

This argument is the most powerful. It does not deny that victims may feel very strongly the desire to take personal action in response to the crime they have suffered. On the contrary, it is precisely because it recognizes the power of that desire that it views it as a threat to the most objective and consistent justice that is humanly possible. The dangers of inconsistency and arbitrariness created by the intervention, however marginal, of victims, who are unlikely qua victims to have either the experience or the motive to compare 'their' cases and 'their' offenders with those of others, are significant ones.

This fourth argument could be overturned only by a particularly radical version of the proposition that victims must have ownership of "their" crimes. Its critic would have to maintain that the empowerment of such "ownership" either posed no threat to, or took priority over, the aim of achieving the most objective and consistent justice humanly possible.

It is important to note at once that none of these arguments for the wholly public conception of criminal justice are telling against strict VIE. In strict VIE, it will be recalled, the victim's evidence as to harm is simply evidence to be considered alongside other evidence of harm (clinical, financial, etc.); the victim participates merely as a witness who is best placed to report harm accurately, and has no privileged "voice." The victim may or may not feel gratified at being enabled to present the VIE; such gratification is irrelevant to its purpose. 
Nor do the four arguments tell against many of the forms of victim support advocated, and in many cases introduced, in recent years. In the UK, for example, Helen Reeves and Kate Mulley summarized the entitlements they proposed for crime victims under five headings. Four of these are: compensation (to restore victims to approximately the same financial position as before the crime); protection (against intimidation, harassment, and invasions of privacy); services expressly dedicated to their needs, and modeling good practice in the treatment of victims to be emulated by other professionals; and clear information at each stage of the case. Reeves and Mulley's fifth point is that victims should "be free of the burden of decisions relating to the offender. This responsibility lies with the state." Though their contention here is motivated by concern for the welfare of the victim as they perceive it, rather than by the arguments for denying the victim active rights of influence over prosecution or sentencing, it dovetails with them. Reeves and Mulley do support a form of VS, partly for its expressive or cathartic value, partly to ensure that relevant information is documented, and especially to allow fears of retaliation against the victim by the offender or his associates to be heard. They add: "This statement should be taken into consideration whenever decisions are made about the case, including cautioning, charging and bail.” Though the expression "whenever decisions are made about the case" might seem to contradict their view that victims should be shielded from decisions relating to the offender, their prime concern is with the victim's physical and psychological safety, and they reject the use of VIS to influence sentencing. ${ }^{25}$

The arguments do tell, however, with varying degrees of force, against Victim Opinion Statements, since these allow active influence over outcomes to the particular victim, who thereby, in virtue of her special relation to the case, enjoys a power denied to all other citizens. 
It is notable that the counter-arguments that are necessary to negate each of the four arguments for the wholly public conception have a common factor: they all insist that the response to a crime, though discharged through the agency of the criminal justice system rather than through private action, should be conceived as, at least partially, belonging to, or being conditional on the sovereign choice of, the victim.

It is striking how prevalent metaphors of ownership are in the advocacy of all versions of VIS. They can be traced at least as far back as Nils Christie's eccentrically written but influential article of 1977, "Conflicts as Property." Christie advocates "a court procedure that restores the participants' rights to their own conflicts," contrasting the alienating impersonality of Scandinavian, British and American courts with an episode of domestic conflict resolution in a Tanzanian village. "The parties, the former lovers, were in the centre of the room and in the centre of everyone's attention. . . It was a happy happening. . . It was circus. It was drama. It was a court case." Christie does not state and confront arguments in favor of the wholly public conception. Rather, he renders them irrelevant by a strategy that is to recur in later campaigning for VIS: he represents the assumption of criminal justice by the impersonal state as a kind of expropriation of the victims by professionals, especially lawyers. "Should lawyers be admitted to court?" he asks. "Experts are as cancer to any lay body." Instead, he advocates, as an admittedly hard-to-realize ideal, a victim-oriented court, constituted out of local community members, and focused on assessment of the victim's situation and on restitution to him, ideally by the offender himself. Punishment of the offender would be required only where his "constructive" sufferings through restitutive actions were felt to be insufficient to meet the sentiments of the local community. ${ }^{26}$

We should note that Christie himself, writing in the nineteen-seventies, does not conceive of criminal cases as the private property of individuals; their ownership should, in his view, be "shared" by the neighborhood, and it is precisely this sharing that is the benign 
service of his ideal, community-based court. ${ }^{27}$ But it is clear how readily this notion of neighborhood "ownership" could dissolve under the influence of a more assertively individualistic culture, especially since, once the idea is established that the participants should retrieve their conflict from the grasp of the state and its professionals, it is hard to explain why they should then surrender it to their neighbors. It is notable that some, though not all, of the victim comments quoted by Erez appeal strongly to this sense of personal ownership.

More recently, Renee Zaubermann (2000) has drawn attention to the ways in which both individuals and organizations have "instrumentalized" criminal justice for their own purposes, reporting a crime to the authorities when they foresee advantage from doing so, while adopting alternative strategies if they do not. It is not far from this to the perception of criminal justice as a service, available for optional use like any other public service. Like Dubber, Zaubermann does not so much engage with arguments for the wholly public conception, as identify it with the asserted authority of the sovereign state (historically originating in the personal sovereignty of a monarch) as against other political forces. Similarly, much discussion of victim rights in criminology draws on a vision of criminal justice as a space in which competing agencies struggle for influence, the courts and the legal profession being perceived as excessively dominant and the victims, like the offenders, in pressing need of agencies to assert their interests. Advocates of restorative justice often strike a similar note. Charles Barton, for example, criticizes the Justices of the New Zealand Court of Appeal who, in The Queen v. Clotworthy (1998), overturned the District Court's decision to accept agreed compensation to a victim in lieu of a custodial sentence for the offender, giving priority to the public interest in "consistency, integrity of the criminal justice system and deterrence of others" over the wishes of victim and offender. ${ }^{28}$ Barton comments that 
rather than showing respect to the wishes of the primary stakeholders, and especially those of the victim, they presumed to know better how the case should be resolved. . . Judgments such as this only succeed in supporting calls for a substantial and urgent transfer of power from the professionals of the legal system to the primary stakeholders. $^{29}$

The salient points here are the imputation to the "professionals" of defective understanding, implicitly grounded in the arrogance of their professionalism itself ("they presumed to know better"); and the market-liberal model contained in the repeated use of "stakeholders": a business expression that has been gradually colonizing political and publicservice discourse over the last decade or two. ${ }^{30}$

In short, insofar as they acknowledge at all the arguments for the wholly public conception, commentators sympathetic to victims' voices tend to treat them as merely strategic justifications for state power and the authority of the courts, or as necessarily yielding at least some ground to the victims' right of "ownership." The implicit slogan is: "the crime belongs to the victim, not to the officials of the state." As we shall see, the same conception emerges elsewhere in the case for VIS.

\section{The restoration of 'balance'}

I turn now to the second question. Erez's respondents were not alone in suggesting the need to correct the "unequal balance" between victim and offender, in part through the introduction of VIS. This metaphor of "balancing," as between the respective interests of the individual offender and victim, or between the legal rights of accused persons and the "rights" of the wider population, is extensively used in the wider political and media discourse, always with the prior claim, or implication, of an existing imbalance in the criminal justice system in favor of the offender or alleged offender. ${ }^{31}$ Whatever the general 
merits of such claims, we are concerned here specifically with the arguments for allowing victim input as part of the "rebalancing" strategy.

Two quite different aims of the "rebalancing" campaign need to be distinguished. One, corresponding to the justice-based justification of victim input, is to ensure that the accused does not benefit unduly, in the determination of his punishment, from what one might call superior communicative entitlement as compared to the victim. The underlying assumption here is that, prior to the introduction of VIS, the accused has enjoyed an unwarranted superiority of communicative entitlement. The other aim, corresponding to the welfare-based justification, is to ensure so far as possible that the presumed victim is not further afflicted by the experience of the criminal justice process itself, and indeed to offer him or her opportunities for healing and compensation wherever this is feasible. The underlying assumption here is that, for many victims, their experience of the criminal justice process is that it adds further affliction rather than bringing healing, and that they are accorded less respect, care, and considerate attention than the accused.

The arguments that follow later in this section are directed primarily against the justice-based justification. Clearly the welfare-based justification is confirmed by the experiences of many victims, and no-one could reasonably deny that -provided these do not compromise the pursuit of a just verdict and proper sentencing- efforts at comfort, healing, and restoration of self-respect for the victim should be made. These might include the victim statement, understood not as a medium for supplementary evidence, but as an opportunity to express damned-up feelings to an attentive and sympathetic audience, and to make a public affirmation of important personal values that have been outraged by the crime. For example, the court in a recent domestic child abuse case in Australia, having heard amid other harrowing evidence that the father had violated his younger daughter with the hilt of a hunting knife, probably did not need, as information, to be told in the clichéd phrasing of a 
VIS that the children's "home life was rotten to its dysfunctional core."32 But it is entirely credible that such a statement by a victim could have therapeutic value. It could help the victim to dissociate herself, through the rhetoric of vivid condemnation, from memories that might threaten to enslave her psychologically and to engender irrational guilt. And it might bring her the relief that is often achieved when a hitherto private anguish is brought under a widely-recognized public concept (“dysfunctional family”), and we feel that we are not unique in our suffering, and that there is a system of ideas that embraces it. The cliché is itself comforting.

The difficulty in accepting the welfare case for VIS lies with the proviso about preserving justice. It is precisely in respect of VIS, as contrasted with other devices of victim support, that the distinction between enhancing victim welfare and achieving just punishment of the crime is most difficult to sustain in practice. The discourse both of the "rebalancing" campaign, and of victim statements themselves, often conspicuously fails to distinguish a therapeutic aim from an aim of achieving justice. How, for example, should we interpret this passage?

I am grateful that this legal part of my brother's death will soon be over. I have realized that no plea, no sentence, no punishment is really going to make me feel better. My brother is still dead, and my family still has to deal with his violent death. . . . No length of incarceration will take the pain away from my family. No sentence will bring my brother back. All the members of my family have a life sentence of grief. ${ }^{33}$

The statement voices grief and suffering, and affirms the solidarity of the surviving family members: in the very act of denying the possibility of consolation, it perhaps achieves a small alleviation of pain, if only through the dignity of its utterance. At first, it seems also to 
disclaim any voice in the punishment of the killer: "no punishment is really going to make me feel better." But that "really" is already a crucial qualification. "No sentence will bring my brother back" can imply either "I am indifferent to any sentence" or "No sentence can be long enough to equate to my loss." On the latter reading, the denial of any quest for retaliatory satisfaction is a mere preamble to the final hint that (for implied reasons of balance-we have received a life sentence) the offender should receive the maximum punishment available. Such multiple ambiguities of meaning and purpose - and this example is hardly an unusual one-make it difficult to accept that a therapeutic "rebalancing" as between offender and victim can be carried out without at the same time allowing the victim a communicative entitlement that requires support from the justice-based "rebalancing" argument. To this I now turn.

There are two main justice-based arguments that use the balancing metaphor. The first maintains that victim input can inform a process of restitutive justice, repairing or compensating the harm suffered by the victim, and so correcting, or mitigating, the unbalanced distribution of goods and harms created by the crime. The second relates specifically to the sentencing phase, and justifies the presentation of evidence about the impact of the crime on the victim on the grounds that it "balances" evidence about the offender's character and history presented in mitigation. I shall discuss each in turn.

Intuitively, a crime often does place an offender at an advantage relative to the victim. The clearest examples are economic crimes such as theft, burglary or vandalism. Restoring the status quo ante by reimbursing the victim at the offender's expense, where this is practicable, can plausibly be said to restore a balance. But even with these crimes, direct financial restitution has only limited restitutive power. There is more to suffering criminal damage, for example, than a financial loss. If I find my car tires slashed, I am unlikely to feel 
that equilibrium has been restored merely by the reimbursement of the costs of replacing the tires: I have to cope with a psychological harm, the awareness of the hostility or contempt that motivated the act.

Considerations of this kind have led writers such as David Hershenov (1999) to suggest that the gratification of feelings of revenge can provide restitution where financial compensation fails: that the victim may be satisfied that the imbalance has been corrected if she can see that the offender has had her "comfort level" lowered proportionately to the harm done by her offense.

A case for victim input for purposes of balance could perhaps be made along Hershenov's lines. On this view, once we have moved beyond the kinds of financial harms that can readily be documented, we will need advice from the victim if we are to assess correctly the type or level of discomfort that the offender will have to endure in order to correct the imbalance of harms.

To justify such an approach, we would need to have great confidence in the ability of the courts to elicit an objective quotient of harm from VIE. Moreover, it is controversial, to say the least, that punishment should be proportional to the harm caused, rather than to the blameworthiness of the offender's action, ${ }^{34}$ let alone calibrated to correct any remaining imbalance of comfort as between victim and offender. If, indeed, the actual imbalance between these two individuals had to be redressed, then the aim of equal punishment for objectively comparable cases would have to be abandoned in favor of a strict calibration of punishment to the distress of the particular victim, who may be either more or less than averagely sensitive. I return to this point in VI below.

Unsurprisingly, most advocacy of enhanced victim input for reasons of "balance" does not demand this kind of scrupulous rebalancing of harms and discomforts in the ultimate outcome. Rather, it suggests that in its process of determining just punishment, the court must 
receive appropriately "balanced" input to its deliberations from the respective voices (actual or representative) of offender and victim. Hitherto, it is supposed, there has been an imbalance in favor of the offender.

The difficulty here is to see how any new communicative entitlement granted to the victim (such as the right to a VS) could credibly be described as restoring a disrupted "balance" in relation to a communicative entitlement of the accused, since, under the current criminal justice process, these two parties are in asymmetric positions, with disparate communicative needs. The accused is on trial, facing the threat of punishment, and needs to communicate his defense point by point in response to the prosecution's case; the victim, in contrast, has an ancillary role and may not even be present throughout the proceedings. The victim's ordinary (non-VIE) evidence may already "balance," in the sense of countering, some assertion of the defense; and with the arguable exception of mitigation (see below), other communications by the accused have no obvious equivalent from the victim's side. To achieve comprehensive "balance" in communicative entitlement, the process itself would need to change, so that offender and victim would indeed become the antagonists, or at any rate equal parties in that "three-cornered contest" model repudiated by the Irish Minister of Justice. In that situation, both would require full-scale legal representation and, in principle, equal air time. The metaphor of victim-offender balance, in short, presupposes, when applied to communicative entitlements, the substitution of an individually adversarial for the wholly public conception of the criminal justice process. ${ }^{35}$

The main focus of this second argument for allowing victim input as part of a balancing strategy is the claim that VIS offers an appropriate counter to mitigation evidence, that, uncorrected, provides an unfair advantage to the defense at the sentencing stage. Here, at least as far as the United States is concerned, the accusation of "law bowing to politics" is as old as the Supreme Court decision in Payne v Tennessee (1991), which held that the Eighth 
Amendment did not bar juries in capital sentencing cases from considering, alongside evidence presented in mitigation, VIE of the victim's character and the emotional impact of the murder on the victim's family. On that occasion, both sides alluded to the influence of victims' rights campaigns on the majority opinion. ${ }^{36}$ The constitutional arguments are complex, and much of the debate lies beyond the scope of this paper, ${ }^{37}$ I focus here simply on the powerful rhetorical role played by the appeal for restoration of balance between the voices of criminal and victim. Joshua D. Greenberg quotes the words of the Supreme Court of Tennessee.

It is an affront to the civilized members of the human race to say that at sentencing ... a parade of witnesses may praise the background, character and good deeds of Defendant ... but nothing may be said that bears upon the character of, or the harms imposed, upon the victim. ${ }^{38}$

If we conceive the court as a theatre in which two rivals, personally or by proxy, strive to assert their dignity, this claim has force; the problem lies in its application to the specific drama of sentencing. It is true that some of the arguments for excluding or constraining VIS at the sentencing stage are symmetrically applicable to mitigation. As Greenberg points out, critics of VIS object that its power to influence sentencing may depend on whether the victim or victim's survivors are articulate enough to express their experiences and feelings effectively to the court (which may in turn depend on their being socially or ethnically similar to the judge or jury). But the same applies to statements in mitigation by the defendant's allies: a defendant with middle-class, university-educated family and friends is likely, all else being equal, to benefit from more persuasive mitigation statements than an unloved drifter. Concerns over the difficulty in maintaining consistency from case to case in 
the weight to be given to elements in VIS also arise no less strongly with mitigation statements. $^{39}$

However, these similarities between certain arguments applicable to the two types of evidence do not mean that mitigation and VIS should properly be regarded as balancing one another. Indeed, as others have pointed out, they are radically different. ${ }^{40}$ Mitigation statements do not, for the most part, concern themselves at all with the harm suffered by the victim. They typically assert the defendant's general good character, or cite his remorse, cooperation with the police, or good conduct as a prisoner. Their characteristic aim is to convince those responsible for deciding on the appropriate sentence that the particular crime has been an aberration by an essentially good (or at least, less bad than the crime might suggest) individual; or, more abstrusely, but not uncommonly where there is a long delay between crime and punishment, that the person now facing punishment is less dangerous, or more morally regenerate, than the person who committed the crime. ${ }^{41}$ Evidence as to the harm suffered by the victim or her associates or survivors cannot relevantly "counter" such claims at all. The true 'counter' would be evidence of the defendant's generally bad character, lack of remorse, and so forth.

Direct contradiction between mitigation and VIS would arise only if the mitigation statement attempted to minimize the harm sustained by the victim, or if the VIS assailed the defendant's wider character or conduct, over and above the crime itself. If the idea of VIS and mitigation "balancing" one another was enshrined in the criminal justice process, it is conceivable that such counter-arguing (and counter-counter-arguing?) would be attempted; if this were to occur, the distinctive functions of mitigation and of VIS would come to subserve a contest between two individuals (or their representatives) each seeking to position himself, on a spectrum of "deserving" character, as favorably, relative to the other, as the most generous construal of the evidence will allow. 
The Supreme Court judges who upheld the constitutionality of VIS in capital cases sometimes invoked an idea that seems to be intended to fend off the objection that VIS turns public criminal justice into a private combat between individuals. This is the idea that victim impact evidence can demonstrate "the particularized harm that an individual's murder causes to the rest of society" [italics added]. ${ }^{42}$ This function of VIE may be interpreted as a response to the mitigation evidence that suggests that the offender is of sufficient actual or potential worth to society to merit being kept alive. Yet even in this aspect, VIE is not truly 'counter' to mitigation evidence. For however great the loss to society caused by the death of a homicide victim, this cannot affect the question whether the killer's death will represent an unacceptable loss of worth to society. If worth to others is the criterion to be considered, then the loss of a person even of very high worth to others does not provide a reason for the removal of a person of lower worth. Once more, the true counter to mitigation in this regard would be evidence that the offender is of lower worth to society than the defense claims, not evidence of the superior worth of the victim.

As Greenberg remarks, the persuasiveness of the Tennessee Supreme Court's statement is more political than judicial. It rests on a presupposition that "the criminal justice system neglects crime victims while privileging defendants, ${ }^{43}$ implying that every opportunity must be taken to give the victim a voice. More fundamentally still, it implicitly presents judicial proceedings as a contest for entitlements between two individuals, even at the point at which the specific purpose of the proceeding is to determine the punishment of one individual alone.

\section{The determination of just punishment}

The third question arises from the use of strict VIE. According to strict VIE as I have defined it, evidence of the impact of the crime on the victim and those closely connected to her is presented for the better information of the court, on the same footing as clinical or financial 
evidence of the consequences of the crime, and without implying any special expressive role for the victim in the court proceedings. It would be just as acceptable if the same evidence could be presented impersonally, without any participation at all by the victim.

An immediate criticism of this conception is that, if the VIE is impersonal in this sense, it is not clear why a separate ritual of presenting it should be needed, nor why it should be presented at a separate point, such as the sentencing phase. Why should all evidence of the consequences of the crime not be presented at once? Indeed, is it not only when all consequences have been spelt out that we can understand precisely what the crime has been?

In answer to this last question, we need to recall that a criminal offense is defined in terms that specify or imply certain types of actions having certain types of consequence, but do not specify or imply other consequences that are nevertheless entirely possible in particular cases. For an action to constitute murder or manslaughter, for example, it must be a consequence of the offender's actions that someone is dead. But there is not a distinct offense of "causing the death of the best Heldentenor of his generation, thus diminishing the pleasure of audiences at the Bayreuth festival for the next twenty years." Such consequences are not sufficiently generic to form part of the definition of an offense. We therefore maintain a distinction between those consequences of the defendant's actions that must be proved in order to establish that the offense has occurred, and various other consequences that may influence our more refined judgment of the offender's blameworthiness.

Let us suppose that $\mathrm{M}$ murders $\mathrm{V}$, who happens to be the father of several young children and the leading Heldentenor of his generation. We will find it useful to distinguish the following:

A Direct consequences of the defendant's action that are a condition of the occurrence of the offense. 
B Direct consequences of this type of action that are a condition of the definition of the offense.

C Indirect consequences of the defendant's action that he in fact foresaw.

D Indirect consequences of the defendant's action that he did not in fact foresee.

E Indirect consequences of this type of action, of a kind that could be expected to be foreseen by any reasonable and averagely well-informed person.

F Indirect consequences of this type of action, of a kind that could not be expected to have been foreseen by any reasonable and averagely well-informed person.

If we apply these to the Heldentenor case, the A and B consequences are the same: that someone dies. These make the case one of homicide. The difference is simply between token and type.

C consequences might, in principle, influence our sense of the heinousness of the crime. If $\mathrm{M}$ knew he was creating grieving orphans or disappointed opera-goers, and especially if he intended to do so as well as to deprive $\mathrm{V}$ of his life, this could only increase his blameworthiness, since he would have envisaged, or even aimed at, additional suffering for additional victims. Conversely, therefore, if ( $\mathrm{D}$ consequences) $\mathrm{M}$ did not know that $\mathrm{V}$ was a parent or a singer, we might condemn him a little less. But evidence to support such judgments at a trial could not be presented as VIE. It would be necessary to show, not whether in fact V had children who suffered, but whether M knew that V had children who would suffer. 
E consequences form the basis of most attempts to reflect in punishment the harm done by a crime. Reflecting the principles (i) that crimes and their legal penalties should be publicly promulgated and (ii) that agents should be held responsible only for those consequences of their actions that they could reasonably have been expected to foresee, the courts take account, not so much of the $\mathrm{C}$ and $\mathrm{D}$ indirect consequences of the actual crime, as of the type of consequences (E) that predictably follow this type of act. Generalizing in this way establishes a norm that can be applied to all cases; it invokes an understanding of the seriousness of a given type of crime that is expected to be shared by all mentally competent citizens. (And this shared understanding is partly what justifies the law's prohibiting the offense, and the severity of the penalties applied to it.) A reasonable person should be expected to foresee emotional distress to a murder victim's family and friends, and this expectation is folded in, so to speak, to our assessment of the heinousness of this type of crime. But just for that reason, E consequences do not require any special kind of evidence. Indeed they function morally even if, in the particular case, the relevant consequences did not occur. The murderer should not, where E consequences are reflected, be punished more lightly because, as a matter of fact, $\mathrm{V}$ has no family or friends to grieve for him; his blameworthiness reflects the fact that there might have been grieving survivors, and he could reasonably be expected to have been aware of this possibility. Conversely—so far as E consequences are concerned — he should not punished more severely because the grief of the survivors is especially intense or widespread.

But just as a reasonable person qua potential murderer is assumed to be able to foresee certain possible indirect consequences of the type of act he commits, so a reasonable person qua judge or jury member is assumed to be able to foresee them. Therefore, to secure a just level of punishment, no special presentation of evidence is required. A special presentation would be needed only if it were true that 
E1 Judges and jury members (where the latter participate in sentencing decisions) are, in consequence of their roles, especially deficient in the capacity to understand and take account of E consequences.

We would need very strong arguments to support E1, since it amounts to saying that those expectations (of insight into foreseeable consequences of certain types of action) that the courts apply to offenders cannot be assumed to be met by the courts themselves.

F consequences ought to be set aside by the same arguments that endorse the use of $\mathrm{E}$ consequences. If a particular consequence (such as the declining standards of singing at Bayreuth) is not of a type that could have been foreseen to result from this type of act, then (i) it could not have entered even implicitly into the public promulgation of murder as an offense meriting penalties of a certain severity; and (ii) to punish the offender specifically for causing this consequence would be unfairly to hold an agent criminally responsible for a consequence of his action that he could not reasonably be expected to have foreseen.

This last point is perhaps controversial. Jurists and philosophers have debated the propriety of allowing the severity of punishment to reflect 'consequential moral luck': consequences less severe or more severe than might have been expected. This question cannot be explored in all its bearings here. ${ }^{44}$ The crucial point for our current discussion is that we do not need to reject argument (ii), and move in the direction of strict liability for consequences, in order to hold serious offenders to account for serious indirect consequential harms. Any reasonable and averagely well-informed person knows that the potential range and seriousness of the indirect consequences of murder are very great. The epistemic obligation - the duty to draw on one's knowledge of the world to envisage possible consequences - rightly weighs very heavily on the person who intentionally kills. Admittedly, 
no-one randomly murdering a stranger could specifically predict that he would be the world's leading Heldentenor, or the lone parent of six children, or a cancer specialist on the brink of a major research breakthrough; but anyone should realize that the murder of another human being might have unexpectedly wide-ranging, painful or long-lasting consequences. It is not like the unexpectedness of stealing, and then throwing away, a cigarette packet that turns out to have contained a priceless jewel in a secret compartment.

Just because the potential range and seriousness of the indirect consequences of murder is sufficiently predictable, we can reflect that range in our punitive judgment of the crime of murder in general. We hold murder to be a very bad crime, not only because it deprives one person of her life, but also because it typically causes great collateral suffering. And this is taken to be a matter of common understanding: we expect that the offender will be aware of it, and we expect that judges and jury members will be aware of it. We would need a very strong argument to set aside this latter expectation, since it would amount to saying that the expectations that the courts apply to offenders could not be applied to the courts themselves.

There is therefore no need, in order to reflect in punishment the heinousness of a crime, for a special presentation of evidence of the particular harm suffered by the victim or her survivors, unless this harm is even more serious than that which (in the form of the predictable range and seriousness of the potential consequences of this type of crime) should be assumed to be a matter of common understanding. ${ }^{45}$

Because the predictable range of harms caused by murder are so dreadful, this need to learn of particular harms is easier to imagine with crimes less serious and far-reaching than murder. If T steals and discards V's specially adapted cigarette packet, it may be as much of a surprise to the court as to $\mathrm{T}$ that it contained a priceless jewel representing most of V's wealth. The court might need victim impact evidence to inform it of this indirect consequence. Such 
consequences do not fall within the predictable range and seriousness of the potential consequences of such petty theft, and so the standard punishments for theft do not sufficiently reflect them. But in these cases, the force of our concerns over consequential moral luck seems especially strong. It would be unjust to punish the thief more severely because of a consequence he could not reasonably be expected to have foreseen or (which is the same thing) the possibility of which is not part of the understanding of this type of crime that ought be assumed to be shared among all citizens.

In short, if the court can assess for itself the heinousness of the crime by referring to the predictable range and seriousness of the potential consequences of this type of crime, it does not need VIE. If there are more serious consequential harms from this offense than the predictable range would encompass, the court might learn something from VIE; but it would then be unjust to punish the offender more severely on account of that information, since this would be holding him accountable for a duty to envisage consequences that those authorizing the punishment could not themselves normally have envisaged.

The principle underlying this conclusion is that criminal responsibility and eligibility for punishment are bounded by common understandings — by our capability of deploying knowledge that is accessible to and is shared, or ought to be expected to be shared, by all citizens. (Criminal responsibility is correspondingly diminished in the case of those incapable of achieving or deploying such knowledge.) And the two premises that would legitimize the special presentation of VIE in spite of the arguments presented above have in common their rejection of this principle. One is E1, the claim that the courts cannot be trusted to understand "consequences of a type of crime of a kind that could be expected to be foreseen by any reasonable and averagely well-informed person." According to this claim, the courts would need the special presentation of VIE in order to bring them up from their defective level of understanding to that of a reasonable and averagely well-informed person, such as the 
offender is expected to be when held accountable for his crime. Though unlikely, perhaps, to be believed by professionals within the criminal justice system, this claim has its adherents among the general public and in the media, convinced that courts and especially judges are "removed from the community" and in need of continual reminders of the serious consequences of crime. ${ }^{46}$ The continual exposure to evidence of crimes is presumed to desensitize the courts to individual instances, rather than to inform consistent judgment across cases in general. The best proof that this view exists and has influence is that judges and criminal lawyers themselves defensively acknowledge it. ${ }^{47}$

The second is the claim that E consequences, defined as they are in terms of types of action and types of consequences, are an insufficient or inappropriate basis for determining punishment; that actual consequences of the particular crime, even if they are less or more severe than the average, should calibrate punishment. VIE is necessary, according to this claim, because it helps the courts to fix punishment to counterbalance more precisely the actual suffering of the particular victim. As Hershenov says of victims who happen to have suffered particularly badly, or cannot be financially compensated, "since they were hurt more, they need more compensation" (that is, in the form of more severe punishment of their afflicter). ${ }^{48}$ But to go beyond E consequences in this way-and this is precisely the role that VIE can play-is to move from a conception of criminal liability as founded in common understandings that are expected to be shared by all competent citizens, to a conception much closer to that of civil liability, in which actual "loss" must be compensated. On this point, there is evidence that the claim is supported, not only explicitly by certain philosophers, but implicitly by some criminal justice professionals, since the guidance to victims on completing victim impact statements commonly encourages a specification of losses reminiscent of an insurance claim, and an expectation of restitution. ${ }^{49}$ 


\section{The two presuppositions and their political basis}

The analyses in the three preceding sections all point in the same direction. The arguments for enhanced victim input into the criminal justice process itself are open to significant objections, unless they are reinforced by the acceptance of two tacit presuppositions.

Presupposition one is a conception of society as a collection of individuals seeking, and entitled to, their due. This in turn yields a vision of criminal justice, not as the realm of steadfastly maintained objective and public norms, but as a field of interpersonal conflict, a battle among individuals for relative advantage, recognition, influence and other goods. The crime victim is no longer conceived as a citizen with an interest in criminal justice identical to that of all other citizens (though happening to be the occasion of one specific prosecution, and in addition having certain specific welfare needs). Rather, he or she is conceived as an individual contesting power over, or "ownership" of, "her" case with another individual, the defendant.

Presupposition two is that the courts (meaning judges and jury members) are less well equipped than the averagely reasonable and well-informed person to weigh for themselves the enormity of the type of crime prosecuted before them. Confronted, for example, with an act of mass murder, they cannot be left to imagine for themselves the kind and degree of harm that it might have done- even though they expect the offender, unless excused from the epistemic responsibilities of an averagely reasonable and well-informed person, to have imagined it, since on just those terms they are holding him criminally responsible for it. It is not enough for the courts to know that the corpses of small children had to be dug out of a bombed building; they need to hear expressly of the agony of rescue workers, who noticed that one dead child had a teddy bear on his shirt, another a brick embedded in her head. ${ }^{50} \mathrm{Or}$, on the side of leniency, they need to hear a victim's survivor point out that "My dad is gone now, and there is nothing that can make that enormous loss whole." ${ }^{.51}$ The enhancement of 
their insufficient imaginings by this kind of especially vivid testimony is supposed to assist them in judging whether, for example, the harm done by mass murder justifies a death penalty, or merely life imprisonment.

Whether these two presuppositions are defensible cannot be resolved here. The first involves a radical claim about the nature of criminal law; the second is an empirical proposition to be investigated by sociologists or psychologists. What is clear is that they are more likely to be believed, or half-believed, by the general public, at least within Anglophone jurisdictions, today than a generation ago. The reasons for this are, once more, a sociological question, but some clue may be given by two common factors that the presuppositions possess. Firstly, the assertion of their truth disparages the public realm. Presupposition one rejects the wholly public conception of criminal justice in favor of an individualistic and competitive model reminiscent of economic liberalism. Presupposition two says that people who take up public roles are, to the extent that they fall into their role, to be especially suspected of being out of touch with human reality.

The second common factor is that both presuppositions are entrenched in the attitudes and practices of the mass media. ${ }^{52}$ The clichés of victim impact and opinion statements delivered in court echo those delivered by (or elicited from) victims or their survivors in media interviews. In jurisdictions where the most severe penalty for murder is literal life imprisonment, the grieving survivors of a murder victim will often say-we have already seen an example - that they themselves have been "condemned to a life sentence." Some of them, at least, must now be saying it because they have heard others say the same on television. ${ }^{53}$ Those pronouncements in turn echo, or are echoed by, leader-writers and columnists whose mission is to campaign for the decent person to get his or her due. The courts become most visible in this discourse when they are perceived as obstructing the 
decent person's quest, either through fussy adherence to legal technicalities, or because of failures of human sympathy from the bench.

To a certain extent this orientation of the media is inevitable because of the internal imperatives of broadcasting and print journalism. Competing for market share, the media need vivid human stories, and they need them as quickly as the risk of contempt of court will allow; and they need heroes, victims and villains pitted against one another, rather than the patient and dispassionate application of doctrines and norms. Judges, professionally obligated to pursue the latter, looking beyond the excitements of the individual case, are always liable to appear to understate the human factor. Juries permanently sworn to secrecy, as in the UK, must also be a source of frustration. (Hence the eagerness with which the press seizes on incidents of weeping or fainting among jury members.)

But the explanation, I believe, is ideological as well as commercial. In the main Anglophone societies, even the conservative media, most conspicuously represented by the Murdoch empire, are philosophically anti-statist. While more likely than the left-wing media to support specific measures of "strong government," especially in foreign affairs and in the fight against crime, they are at least as suspicious as their leftist colleagues of the public establishment and those who populate it. Thus the legitimate activity of the media in holding political leaders and public servants to account hardens into a model of society as divided between the world of established institutions, including the courts, and the world of human flesh and blood. The individual crime victim marginalized by the legal establishment fits perfectly into this picture. The greatly enhanced political possibility of VIS over the last quarter-century may owe as much to its concurrence with this development, as to changes in social values, or in the philosophy of crime and punishment. 


\section{NOTES}

[I am grateful to John Kleinig, Terry Hopton, Nick Currie and a number of anonymous referees for invaluable criticism, advice and encouragement.]

${ }^{1}$ Alan Howe, “They Broke Her Heart,” Herald Sun (Australia), September 20, 2010, 22.

${ }^{2}$ Examples of intrinsic goods would be "the good of justice," or "the good of the existence of beauty," in each case conceived as independent of any benefit to persons. Examples of irreducibly social goods would be "the honor of Japan," or the collective worship of the patron deity of the society, or the achievement by the society as a whole of high ethical or cultural ends.

${ }^{3}$ By "collectively acting individuals" I mean, as explained later in the text, individuals participating in public institutions that require the willing subordination of some immediate advantage or preference, even if each individual believes she will, or may, personally benefit from such participation in the long run. Examples would be the payment of taxation, or of a membership subscription to an organization; military or jury service; or simply accepting that a particular public good to that, with others, one contributes, by payment or labor or mere compliance, may not immediately benefit oneself. On this definition, everyone in a developed society performs some collective actions, so the polarized formulation in the text is too glib. But the polarized ideals —of maximum individual freedom and self-sufficiency, or maximum social cooperation and solidarity, as their adherents might express them—are clear enough.

${ }^{4}$ F. A. Hayek, Law, Legislation and Liberty (London: Routledge \& Kegan Paul, 1976), vol. 2, 1.

${ }^{5}$ Robert Nozick, Anarchy, State and Utopia (Oxford: Blackwell, 2001), chap. 7, 149-231.

${ }^{6}$ Rupert Murdoch, “Free Markets, Free Minds," Inaugural Margaret Thatcher Lecture, Centre for Policy Studies, London, October 21, 2010, http://www.cps.org.uk/cps_catalog/Rupert\%20Murdoch\%20Inaugural\%20Margaret\%20Thatcher\%20Lecture.p $\underline{\mathrm{df}}$, accessed October 28, 2010.

${ }^{7}$ See John Rawls, A Theory of Justice (Cambridge Mass.: Harvard University Press, 1971), chap. 8, 453-512, especially sections $75,490-96$.

${ }^{8}$ For classic analyses of the potentially collectively self-defeating character of merely aggregated individual choices, see Derek Parfit, Reasons and Persons (Oxford: Clarendon Press, 1984), Part One, especially chapts. 2 and 3, 53-86. 


\footnotetext{
${ }^{9}$ It is also not, of course, an original idea. For example, Anne James and John Raine have suggested, if tentatively, that the rise of "victimology" in the UK was connected to the "customer-oriented" model of public services that developed in Britain during the 1980s. See Ann James and John Raine, The New Politics of
} Criminal Justice (London: Longman, 1998), 71. See also Renee Zaubermann, "Victims as Consumers of the Criminal Justice System?," in Integrating a Victim Perspective within Criminal Justice, ed. Adam Crawford and Jo Goodey (Aldershot: Ashgate, 2000), 48.

${ }^{10}$ Markus Dirk Dubber, Victims in the War on Crime (New York: New York University Press, 2004), 3-4.

${ }^{11}$ Ibid., 335.

${ }^{12}$ Ibid, 4.

${ }^{13}$ Edna Erez, "Integrating a Victim Perspective through Victim Impact Statements," in Integrating a Victim Perspective within Criminal Justice, ed. Adam Crawford and Jo Goodey (Aldershot: Ashgate, 2000), 179.

${ }^{14}$ The role ascribed to VS in restorative justice theories often seems to straddle these two types of justification. The test that separates them is the unconstrained consent of the offender to the restorative, or reconciliatory, discourse. A convicted offender is unlike the rest of us in that he may have certain specified things lawfully done to him, as punishment, without his consent, but he retains various human and civil rights which mean that his consent is required for activities that are not punishment. On which side of the line dividing the offender's punishment from his sphere of unconstrained consent does the restorative/reconciliatory dialogue lie? If the offender freely consents to the dialogue, then it belongs to the sphere of welfare not that of justice, since whatever benefits accrue — and we can accept that there may be many—are contingent on this initial choice. It is good if they happen, but if they do not happen, no principle of justice has been infringed. But if - or to the extent that — the offender's consent is a product of coercion, or of pressure based on a trade-off against other sanctions, the dialogue is another form of punishment, and needs to be evaluated as such. It is not necessarily less afflicting than other forms of punishment: a person may feel more personally violated by being constrained to take up a certain standpoint, or to listen attentively to certain information, than by being deprived of physical liberty. See note 34 for a further comment on this point. For defenses of restorative justice that are hard-headed about its punitive character, see Kathleen Daly, "Revisiting the Relationship between Retributive and Restorative Justice," in Restorative Justice: Philosophy to Practice, ed. Heather Strang and John Braithwaite (Burlington, VT: Ashgate, 2000), 33-54, and Charles Barton, "Empowerment and Retribution in Criminal Justice" in the same volume, 55-76.

${ }^{15}$ Erez, "Integrating a Victim Perspective through Victim Impact Statements," 176-77. 
${ }^{16}$ See notes 32, 33, 47, 51 and 53 for examples. Dubber, Victims in the War on Crime, 191-92, makes a similar point (with a more express suggestion that VIE is sometimes used by the prosecution to encourage vengeful sentencing).

${ }^{17}$ Edna Erez and Leigh Roeger, "The Effect of Victim Impact Statements on Sentencing Patterns and Outcomes: The Australian Experience," Journal of Criminal Justice 23, no. 4 (1995), 363-75; Julian Roberts, “Victim Impact Statements and the Sentencing Process: Enhancing Communication in the Courtroom," Criminal Law Quarterly 47, no. 3 (2003), 365-96.

${ }^{18}$ Thomas Hobbes, Leviathan, ed. Richard. Tuck (Cambridge: Cambridge University Press, 1996), chap. XVIII, 214-15; G. W. F. Hegel, Philosophy of Right, trans. T. M. Knox (Oxford: Oxford University Press, 1967), 21921 (sect. 102).

${ }^{19}$ For discussions of this much-debated process, see J. M. Beattie, Crime and the Courts in England 1660-1800 (Oxford: Clarendon Press, 1986), 35-73; W. R. Cornish and G. de N. Clark, Law and Society in England 17501950 (London: Sweet \& Maxwell, 1989), 544-613; Clive Emsley, Crime and Society in England 1750-1900, 3rd ed. (Harlow: Pearson Longman, 2005), 1-20, 183-220, 253-96; Douglas Hay, "Property, Authority and the Criminal Law," in Albion's Fatal Tree, ed. Douglas Hay, Peter Linebaugh, John G. Rule, E. P. Thompson and Cal Winslow (London: Allen Lane, 1975), 17-63; John H. Langbein, “Albion's Fatal Flaws," Past and Present 98, no. 1, 96-120; David Taylor, Crime, Policing and Punishment in England 1750-1914 (London: Macmillan Press, 1998), 109ff.

${ }^{20}$ JUSTICE Committee, Victims in Criminal Justice: Report of the JUSTICE Committee on the Role of the Victim in Criminal Justice (London: JUSTICE, 1998), 109.

${ }^{21}$ Ibid., 70.

${ }^{22}$ Michael McDowell, Speech in the Dáil Éireann, 5 May 2004, http://debates.oireachtas.ie/Xml/29/DAL20040505.PDF (accessed 16 April 2007).

${ }^{23}$ In discussing the communitarian argument I both follow and criticize Sandra Marshall and Antony Duff, "Criminalization and Sharing Wrongs," Canadian Journal of Law and Jurisprudence 11, no. 1(1998): 7-22.

${ }^{24}$ Hegel, Philosophy of Right, 220 (section 102).

${ }^{25}$ Helen Reeves and Kate Mulley, "The New Status of Victims in the UK: Opportunities and Threats," in Integrating a Victim Perspective within Criminal Justice, ed. Adam Crawford and Jo Goodey (Aldershot: Ashgate, 2000), 129-30, 140. Andrew Ashworth, “Victims’ Rights, Defendants’ Rights and Criminal 
Procedures," in the same volume (185-204) draws a similar line between the proper treatment and protection of victims, and the granting to them of rights of active involvement in influencing outcomes for the offender.

${ }^{26}$ Nils Christie, “Conflicts as Property,” British Journal of Criminology 17, no. 1 (1977): 10-11.

${ }^{27}$ Among Christie's inspirations is E.F. Schumacher's Small is Beautiful: A Study of Economics as if People Mattered (London: Blond and Briggs, 1973). Cf. Christie, "Conflicts as Property," 14.

${ }^{28}$ The Queen v. Clotworthy 1998: Appeal Court of New Zealand 114/98. Wellington, New Zealand, 12.

${ }^{29}$ Barton, "Empowerment and Retribution in Criminal Justice," 68. For similar arguments see Joanna Shapland, "Victims and Criminal Justice: Creating Responsible Criminal Justice Agencies," in Integrating a Victim Perspective within Criminal Justice, ed. Adam Crawford and Jo Goodey (Aldershot: Ashgate, 2000), 147-64.

${ }^{30}$ The earliest example of this wider sense recorded in the Oxford English Dictionary dates from 1989.

${ }^{31}$ For example: on 20 July 2006 the British Home secretary, John Reid, announced in Parliament proposals which, he said, "all have at their core the aim to rebalance the criminal justice system in favor of the victim and the law-abiding majority" (John Reid, Statement to the House of Commons, House of Commons Hansard 20 July 2006, col. 472.) His Prime Minister had been suggesting a "rebalancing of the system" to this effect in speeches for at least four years (cf. The Independent (London), June 25, 2002, 14-15). American politicians have tended to be more respectful, practically and rhetorically, of the courts' independence. However, as early as 1984, a Presidential Task Force reported to Ronald Reagan that the criminal justice system was "appallingly out of balance.... Somewhere along the way, the system began to serve lawyers and judges and defendants, treating the victim with institutionalized disinterest" (President's Task Force on Victims of Crime: Final Report (1982), http://www.ojp.usdoj.gov/ovc/publications/presdntstskforcrprt/front.pdf (accessed 20 August 2006). By 1996, President Clinton was declaring that “When a judge balances defendants' rights in the Federal Constitution against victims' rights in a statute or a state constitution, the defendants' rights almost always prevail. That's just how the law works today. We want to level the playing field. ... When a judge balances the rights of the accused and the rights of the victim, we want the rights of the victim to get equal weight" ("Remarks of the President at Announcement of Victim's Rights Constitutional Amendment": White House press release, 25 June, 1996, http://www.ojp.usdoj.gov/ovc//publications/infores/62596.htm (accessed 20 August 2006).

32 "Dad Jailed for 20 Years for 'Evil' Sex Abuse of Daughters," Canberra Times (Australia), September 17, 2010, A1.

33 “15-year Prison Term for Killing Bagpiper: Still No Reason or Explanation for Stabbing Friend to Death," 
The Leader-Post (Regina, Saskatchewan), September 14, 2010, A1.

${ }^{34}$ For a powerful criticism of this view, see Joel Feinberg, "Criminal Attempts: Equal Punishment for Failed Attempts," in Joel Feinberg, Problems at the Root of Law (Oxford: Oxford University Press, 2002), 77-102.

${ }^{35}$ Once the criminal justice process is under way, the positions of offender and victim are so dissimilar that a benefit or power granted to the victim by that process cannot, for the most part, credibly be described as balancing a benefit or power of the offender. (An exception is that both could be given equal protection from vengeance by their enemies, if this protection would otherwise be more fully enjoyed by one party or the other.) The claim to represent a restoration of "balance" is also questionable when applied to restorative or reconciliatory dialogues, subsequent to conviction, between offender and victim. These inevitably require a yielding of ground by the offender, and, as Barbara Hudson points out, need to be carefully stage-managed by the authorities, to ensure that the offender cannot re-victimize the victim. Hudson imagines a self-excusing violent offender being brought, through reconciliatory communication, to see that he 'could have' acted differently, to renounce his claim that he "had no choice." (Barbara Hudson, "Victims and Offenders," in Restorative Justice and Criminal Justice: Competing or Reconcilable Paradigms?, ed. Andrew von Hirsch, Julian Roberts, Anthony E. Bottoms, Kent Roach and Mara Schiff (Oxford: Hart, 2003), 183.) If this is a voluntary and unconstrained adoption of a changed view, well and good, but it cannot be called a reestablishment of some kind of pre-existing balance: it is the acceptance by the offender of the view already held by the victim and the state.

${ }^{36}$ See David R. Dow, "When Law Bows to Politics: Explaining Payne v Tennessee," UC Davis Law Review 29 (1992): 157-76. For the relevant passages in the concurring and dissenting opinions, see Payne v Tennessee, 501U.S. 833 (Scalia, J) and 501 U.S. 856 (Stevens, J).

${ }^{37}$ The debate in, and subsequent to, Payne has been structured by the constitutional question over possible arbitrariness in the application of the death penalty. The issue of "balance" in respect of the attention granted respectively to offender and victim has been overlaid, and arguably confused, by the imperative of weighing the respective, and not necessarily symmetrical, risks of (i) executing an offender who does not "deserve" death and (ii) not executing an offender who does. The dilemma of risk created by the drastic and irreversible nature of capital punishment also forces us to confront very difficult questions about the concept of "desert," the relationship between actions and character, and the identity of the self who deserves and receives punishment. For an incisive exploration of these problems, see Evan J. Mandery, "Notions of Symmetry and Self in Death 
Penalty Jurisprudence (with Implications for the Admissibility of Victim Impact Evidence," Stanford Law and Policy Review 15 (2004): 471-517.

${ }^{38}$ Joshua D. Greenberg, "Is Payne Defensible? The Constitutionality of Admitting Victim-Impact Evidence at Capital Sentencing Hearings,” Indiana Law Journal 75, no. 4 (2000): 1379.

${ }^{39}$ Ibid., 1364-65, 1370.

${ }^{40}$ See Mandery, "Notions of Symmetry and Self in Death Penalty Jurisprudence," esp.503-8.

${ }^{41}$ Ibid., 493-503.

${ }^{42}$ Booth v. Maryland, 482 US 496 (1987) at 517 (White, J. dissenting).

${ }^{43}$ Greenberg, "Is Payne Defensible?", 1379.

${ }^{44}$ But see, for example, Dow, "When Law Bows to Politics: Explaining Payne v Tennessee"; Feinberg, "Criminal Attempts: Equal Punishment for Failed Attempts"; David Lewis, "The Punishment that Leaves Something to Chance." Philosophy and Public Affairs 18, no. 1 (1989): 53-67; Michael S. Moore, "The Independent Moral Significance of Wrongdoing," in Michael S. Moore, Placing Blame (Oxford: Clarendon Press, 1997), 191-247.

${ }^{45}$ The offender may, of course, intend some special additional harm, in which case, whether or not it falls within the range and seriousness of predictable harms, that specific intention needs to be proved irrespective of victim impact. An example is provided by hate crimes, in which it may be possible to show that the offender, in injuring or killing $\mathrm{V}$, expressed some malign intention towards a wider community, of whom the direct victim was a representative.

${ }^{46}$ See the epigraph and note 1.

47 'Judge Cooke told the court, 'My own brother was killed by a dangerous driver.' The judge said it was not a case 'in which the judiciary are totally out of touch and do not understand such things.' He said there was, in the general public, a feeling 'that judges live in a different world, where tragedy does not touch their lives. It is not so." (Lauren Turner, "He's my last thought at night and my first thought in the morning, says grieving father," The Western Mail (Cardiff), December 13, 2007, 14.) "Many judges are out of touch with average Australian values and increasingly isolated from the real world, according to a top Melbourne silk. . . . David Galbally QC said part of the problem with the judiciary could lie with the pool of barristers from which they are drawn, who can sometimes have limited life experiences. 'It may be that lawyers who practise in the law and who are barristers are out of touch because of the way they practise law, and they may need to 
be in touch and undertake some form of education from that point of view,' he said." (Richard Kerbaj,

'"Judges Not Living in the Real World," The Australian, January 21, 2008, 3.)

${ }^{48}$ David B. Hershenov, “Restitution and Revenge,” The Journal of Philosophy 96, no. 2 (1999): 79-94.

49 "If you are making a written statement, you may want to discuss how this crime has affected your ability to earn a living and how it has affected you financially. We have also included a separate Victim Financial Statement to help you fully record the financial impact of this crime. It is important to be as complete as possible in describing your financial losses as this information will be used by the probation department and provided to the judge for determining restitution. (Ellen K. Alexander and Janice Harris Lord, "Suggestions for Completing your Victim Impact Statement," in A Victim's Right to Speak, a Nation's Responsibility to Listen, article from the Office for Victims of Crime, sponsored by the US Department of Justice, July 15, 1994, http://www.ojp.usdoj.gov/ovc/publications/infores/impact/impact.htm\#Suggestions

accessed September 24, 2010).

${ }^{50}$ Sergeant Alan Prokop and Inspector Sergeant Jerry Flowers, VIE in the case of the Oklahoma Bomber Timothy McVeigh (United States v McVeigh (1997), June 4, 1997), http://www.cnn.com/US/9703/okc.trial/transcripts/mcveigh.html (accessed 20 August 2008).

${ }^{51}$ Todd McCarthy, VIE in the case of the Oklahoma Bomber Terry Nichols (Tim Talley, "Two who lost family in Oklahoma City bombing testify for Nichols as closing arguments end," Associated Press, June 9, 2004).

${ }^{52}$ It is a disputed question whether, or to what extent, the mass media create or amplify, rather than merely reflect, popular perceptions of the courts' leniency towards offenders and indifference to victims. There is an illuminating discussion in Andrew Ashworth and Michael Hough, "Sentencing and the Climate of Opinion,"

Criminal Law Review (November 1996): 776-87.

53 “A grief-stricken mother delivered a powerful message against senseless violence as she faced her son's teenaged killer and two accomplices in court yesterday. Her voice breaking with emotion, Fredricka Nickie said the unprovoked murder of her son, Kenroy John, by strangers has "condemned her to a life sentence of heartache' without parole.” (Sam Pazzano, “Teen’s Killer Guilty,” Toronto Sun, May 12, 2005, 7.) “This month is hard enough for Ray King, having to relive the pain and anguish of his son's murder 25 years ago at the hands of serial killer Clifford Olson. This week will make matters even worse when Mr. King flies to Montreal to attend Olson's first parole hearing. 'We've got the life sentence — there's no parole for us,' he said of the families of Olson's 11 victims.” (Neil Hall, “Victim's Father to Attend Olson's Parole Hearing," National Post (Canada), July 17, 2006, A6). "The mother of a British woman murdered in Japan six years ago broke down in a 
courtroom yesterday as she described her torment over her daughter's final hours. ... 'When Lucie's killer is convicted of this crime, for me justice demands that he spends the rest of his natural life in prison contemplating the enormity of his crimes. I am living a life sentence because of what he did to my beloved Lucie. He should never be released."' ("Mother of British Kidnap Victim Found Dead in Japan Breaks Down in Court," Daily Mail (London), April 21, 2006 [no by-line].) 